Page 1 of 38

YMP-USGS Map I-2601 Record

Subject/Title: Bedrock Geologic Map of the Central Block Area, Yucca Mountain, Nyc County, Nevada

Record date: 4/17/97

Author: W.C. Day, C. Potter, D. Sweetkind, R.P. Dickerson and C.A. San Juan
Organization: USGS

Pacific Western Technologies

Identifiers: Map I-2601

Traceability designators:

QA designator:

QA :L
SEP: $8 \cdot 3 \cdot 1 \cdot 4 \cdot 2 \cdot 2 \cdot 1$

UBS: 1.2 .3 .2 .2 .1 .2

DIN: GS960708314221.003

This cited reference can be located through the Sechecial Information Center - Site Description Document (SDD): D. nos Delete

of $9 / 29 / 98$

MoL. 19980611.0339 


\section{BEDROCK GEOLOGIC MAP OF THE CENTRAL BLOCK AREA, YUCCA MOUNTAIN, NYE COUNTY, NEVADA}

\section{By Warren C. Day, Christopher J. Potter, and Donald S. Sweetkind, U.S. Geological Survey, Denver, Colorado; and Robert P. Dickerson and Carma A. San Juan, Pacific Western Technologies, Ltd., Denver, Colorado}

\section{INTRODUCTION}

Bedrock geologic maps form the foundation for investigations that characterize and assess the viability of the potential high-level radioactive waste repository at Yucca Mountain, Nevada. As such, this map focuses on the central block at Yucca Mountain, which contains the potential repository site. The central block is a structural block of Tertiary volcanic rocks bound on the west by the Solitario Canyon Fault, on the east by the Bow Ridge Fault, to the north by the northwest-striking Drill Hole Wash Fault, and on the south by Abandoned Wash (fig. 1). Earlier reconnaissance mapping by Lipman and McKay (1965) provided an overview of the structural setting of Yucca Mountain and formed the foundation for selecting Yucca Mountain as a site for further investigation. They delineated the main block-bounding faults and some of the intrablock faults and outlined the zoned compositional nature of the tuff units that underlie Yucca Mountain. Scott and Bonk (1984) provided a detailed reconnaissance geologic map of the area, which was used to help define the most favorable area at Yucca Mountain in which to conduct further site-characterization studies. Of their many contributions, they presented a detailed stratigraphy for the volcanic units, defined several other blockbounding faults, and outlined numerous intrablock faults.

This study was funded by the U.S. Department of Energy Yucca Mountain Project to provide a detailed (1:6,000-scale) bedrock geologic map for the area within and adjacent to the potential repository area at Yucca Mountain, Nye County, Nevada. Prior to this study, the 1:12,000-scale map of Scott and Bonk (1984) was the primary source of bedrock geologic data for the Yucca Mountain Project. However, targeted detailed mapping within the central block at Yucca Mountain revealed structural complexities along some of the intrablock faults that were not evident at 1:12,000 (Scott and Bonk, 1984). As a result, this study was undertaken to define the character and extent of the dominant structural features in the vicinity of the potential repository. In addition to structural considerations, ongoing subsurface excavation and geologic mapping within the Exploratory Studies Facility (ESF), development of a three-dimensional-framework geologic model, and borehole investigations required use of a consistent stratigraphic system to facilitate surface to underground comparisons. The map units depicted in this report correspond as closely as possible to the proposed stratigraphic nomenclature by Buesch and others (1996), as described below.

\section{METHODS}

This report was developed by using standard geologic mapping techniques as outlined in USGS Yucca Mountain Project technical procedure GP-01. The vast majority of the individual contacts were traversed to ensure their accurate depiction and to determine offsets at faults. The field base maps used were topographic maps (10-foot contour interval) composited onto orthophoto maps (1:6,000 scale) developed by EG\&G for the U.S. Department of Energy Yucca Mountain Project. The map area includes EG\&G sheets 10 and 16, the western part of sheets 11 and 17, and the eastern part of sheets 15 and 9. Field work using the composite mylar base maps was compiled onto mylar topographic sheets and digitized using AutoCad (versions 12 and 13). ${ }^{1}$

\footnotetext{
${ }^{1}$ The use of trade, product, industry, or firm names is for descriptive purposes only and does not imply endorsement by the U.S. Government
} 

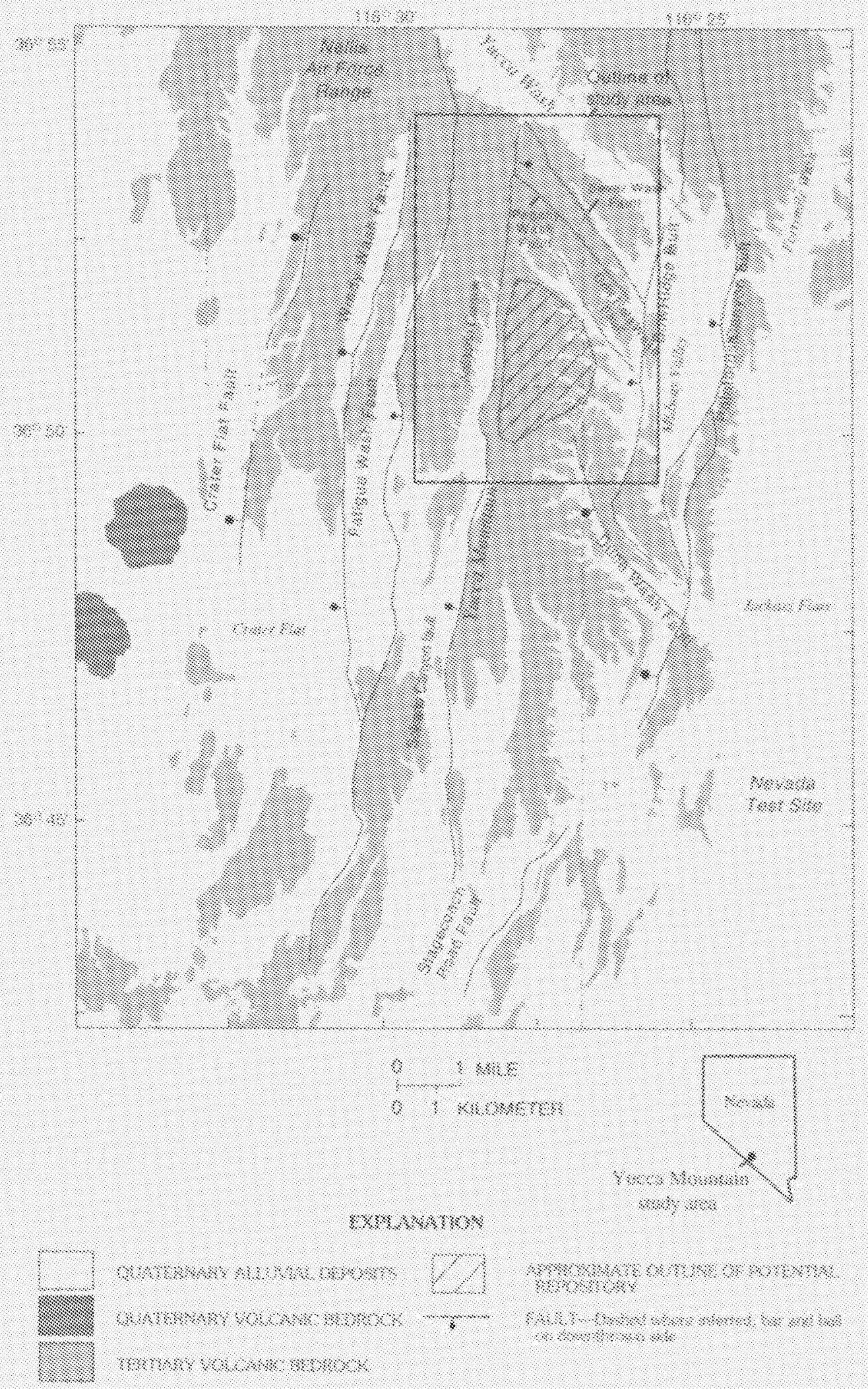

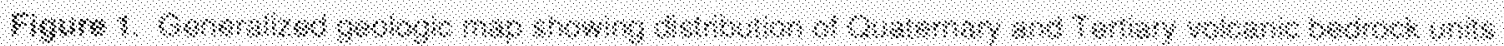

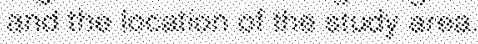


The threshold offset on faults depicted on the map was generally one-half contour interval $(1.5 \mathrm{~m})$ of vertical offset. Delineation in the field of the individual map-unit boundaries is generally within this level of confidence. The map-unit contacts are curviplanar, albeit continuous, surfaces within volcanic units that have inherent thickness and facies variations. In the central and southern parts of the area, the faults through the middle nonlithophysal zone of the Tiva Canyon Tuff (map unit Tcpmn) are difficult to trace. This unit is one of the most ubiquitous units exposed, but it commonly forms debris-covered slopes. Faults are difficult to detect because the unit is massive, densely welded, and brittle and lacks internal marker horizons in this area. Therefore, the number of faults delineated are probably a minimum. However, faults that are internal to Tcpmn with significant offset (greater than $5 \mathrm{~m}$ ) and relatively long trace length (greater than about $100 \mathrm{~m}$ ) or that penetrate an exposed contact and have displacements near the cutoff threshold have been detected. In the northern part of the area map unit, Tcpmn is relatively thin (less than $10 \mathrm{~m}$ thick) and is a very useful marker horizon. Therefore, faults are more readily detected in this unit, which crops out north of Live Yucca Ridge.

Field work to produce this product built on separate detailed mapping campaigns designed for reports internal to the Yucca Mountain Project during February 1995 through June 1995 for areas within the central part of this study area. The mapping of all other areas is original and was conducted by the authors from February 1995 through June 1996.

\section{DATA SOURCES}

Previous mapping done before the development of the Yucca Mountain Project technical procedures included Lipman and McKay (1965), Christiansen and Lipman (1965), and Scott and Bonk (1984). Their work was used as background corroborative information.

The main source of information for the structural control on the interpretations presented in the cross sections was the surface geologic mapping presented herein, which used applicable standard quality-assurance procedures. Stratigraphic thickness information was used from Geslin and Moyer (1995), Geslin and others (1995), Moyer and others (1995), and Moyer and others (1996). Data from Buesch and others (1995) was used as corroborative information to verify the stratigraphic thicknesses for the geologic sections.

\section{BOREHOLE DESIGNATIONS}

Each borehole depicted on the map and used in the study of Yucca Mountain has a unique name or number. Boreholes on the Nevada Test Site (NTS) use an NTS designation (see geologic map for boundary), whereas those off the NTS use a slightly different designation. For example, the full borehole designations for the prefix for boreholes on the NTS begin with UE (for Underground Exploratory) and are followed by the NTS area number (Area 25 in this report; for example, "UE-25"). This prefix designation, "UE-25" commonly is followed by one or more letters that signify the purpose of the hole or simply by a sequential letter, and then by a sequence number. Thus, the designation "UE-25 c\#3" specifies a hole on the NTS in Area 25 and that it is the third hole planned, but not necessarily drilled, at a site named "c."

For boreholes off the NTS (see geologic map for boundary) in adjacent land to the west controlled by the either U.S. Bureau of Land Management or the Nellis Air Force Range, the prefix USW is used (for Underground, Southern Nevada, Waste). For USW boreholes, the series identifier and sequence number are separated by a hypen rather than the number symbol, \#. The first hole planned in the UZ series is off NTS and, therefore, is designated "USW-UZ1." For the purposes of this report, the prefix designators UE-25 or USW are not posted on the map because of space limitations in areas where there are numerous boreholes. Because each borehole designator is unique in this study area, the prefixes are not necessary.

The letters signify the primary purpose for which the borehole was drilled. For example, borehole designations that start with $\mathbf{G}$ were drilled for collection of geologic data; those with $\mathbf{H}$ were drilled primarily for hydrologic data; UZ, for unsaturated zone data; UZ-N, for neutron-logging holes for infiltration data; NRG for collection of data along the north-ramp alignment of the Exploratory Studies Facility (ESF); p, for collection of data on rocks of Paleozoic age; WT, for boreholes that penetrate the water table; and SD, for geotechnical and hydrologic data from a statistically located systematic drilling program. 


\section{NOTES ON STRATIGRAPHIC NOMENCLATURE}

The stratigraphic nomenclature is modified from the informal stratigraphy presented by Buesch and others (1996). Modifications to the terminology were made for the sake of brevity and consistency with the mappable features characteristic of each unit. The hierarchy used herein is highest to lowest rank for age, group, formation, member, zone, and subzone (if necessary). Buesch and others (1996) used this ranking scheme when they proposed an informal stratigraphic nomenclature to be used throughout the Yucca Mountain Project. For example, their unit Tpcpmn can be broken down as follows: the "Tp" as Tertiary Paintbrush Group, "c" Tiva Canyon Tuff, "p" as crystal-poor member, and " $\mathrm{mn}$ " as middle nonlithophysal zone. For this report, to help shorten the unit names, the " $p$ " for Paintbrush Group used by Buesch and others (1996) is dropped inasmuch as both the Tiva Canyon Tuff and Topopah Spring Tuff are within the Paintbrush Group.

Christiansen and Lipman (1965) and Lipman and McKay (1965) initially delineated units in the Paintbrush Group, as well as most of the main lithostratigraphic units within this study area. For example, they gave the Tiva Canyon and Topopah Spring Tuffs member rank within the Paintbrush Group. Sawyer and others (1994) redefined the Paintbrush Group by elevating units defined as members by the earlier workers to formation rank. As such, the Tiva Canyon and Topopah Spring Tuffs are now designated as formations within the Paintbrush Group. Buesch and others (1996) defined informal members, zones, and subzones within the Tiva Canyon Tuff and the Topopah Spring Tuff Formations. In general, both are compositionally similar in that each are quartzpoor ash-flow tuffs with a lower crystal-poor, highsilica rhyolite member overlain by a crystal-rich quartz-latite member. Also, for both formations, the crystal-rich/crystal-poor contact is a continuous compositional break that is regionally mappable. Therefore, for each formation, the member rank is characterized by the crystal content, with the field criteria being that the crystal-rich members contain a crystal content of greater than 7 to 10 percent.

The zonal boundaries in the crystal-rich members used herein are based on primary features such as the abundance and nature of the pumice content. This departs from Buesch and others (1996), who used lithophysal content as observed in drill core as the defining criteria for zones within the crystal-rich members. Lithophysal zones are secondary features caused by exsolution of volatile elements from the ash flow prior to and during lithification. The lithophysalbearing zones reflect, in part, the volatile content of the original ash-flow sheets, which varied locally. Units mapped as primarily a nonlithophysal zone (for example, map unit Tcpmn), therefore, locally can contain lithophysal-bearing horizons. The abundance of lithophysae is quite variable regionally within the basal part of the crystal-rich members of the Tiva Canyon and Topopah Spring Tuffs. For example, lithophysae are locally abundant in the mixed-pumice (map unit Tcr2) and crystal transition zones (map unit Tcrl) of the Tiva Canyon Tuff and within the crystal transition zone of the Topopah Spring Tuff (map unit Ttr 1), although their distribution is irregular and discontinuous. The " $n$ " (and "l"), which Buesch and others (1996) used to define a nonlithophysal (and lithophysal) zone in units within the crystal-rich members, was, therefore, dropped from the equivalent relevant units. For example, units Tpcrn2 and Tpcrl2 of Buesch and others (1996) are herein defined simply as Tcr2; Tpcrn1 (and Tpcrl1) as Tcr1; and Tptrnl (and Tptrl1) as Ttrl, respectively.

The term "pumice-rich zone" is adopted herein to substitute for the name "vapor-phase corroded subzone" used by Buesch and others (1996) for unit Ttrn2 to reflect the primary compositional nature of this rock unit. It is characterized by rich pumice content relative to the rest of the units in Topopah Spring Tuff. The term "vapor-phase corroded subzone" applied by Buesch and others (1996) refers to the secondary alteration phenomenon that affected the unit locally and is not unique nor restricted to this unit.

\section{REGIONAL SETTING}

Yucca Mountain, Nye County, Nevada, lies within the middle Miocene southwestern Nevada volcanic field (Sawyer and others, 1994). The study area is underlain by volcanic rocks of the Tertiary Timber Mountain and the Paintbrush Groups. At Yucca Mountain, these are metaluminous extracaldera tuffaceous deposits (Sawyer and others, 1994) that are made up of variably welded pyroclastic outflow 
sheets and tephra fallout deposits with minor intercalated lava flows, ground surge, and reworked deposits.

The oldest unit exposed in the map area is the quartz-poor 12.8-Ma (Sawyer and others, 1994, p. 1305) Topopah Spring Tuff. This formation is made up of a lower crystal-poor rhyolite member (map units Ttpll, Ttpmn, Ttpmnl, and Ttpul) and an upper crystal-rich quartz-latite member (map units Ttr 1 , Ttrn2, Ttrn3, and Ttrv). Byers and others (1976, p. 24) suggested that the Topopah Spring Tuff probably erupted from the Claim Canyon Caldera to the north of Yucca Mountain. Carr (1986, p. 35) postulated the source caldera of the tuff to be buried under alluvium in Crater Flat to the west of the map area; however, as reviewed by Sawyer and others (1994, p. 1305), the ultimate source caldera remains undefined. Facies relations within the Topopah Spring Tuff around Yucca Wash and north of the map area, however, are consistent with the Claim Canyon Caldera as the most likely source.

Montazer and Wilson (1984) used a combination of the lithostratigraphic units to define the Tertiary Paintbrush nonwelded (PTn) hydrogeologic sequence. The PTn includes the nonwelded bedded tuffs that lie between and include the top of the Topopah Spring Tuff and the basal-most part of the Tiva Canyon Tuff. As originally defined in Montazer and Wilson (1984), the PTn hydrogeologic unit extends from the nonwelded part of the crystal-rich Topopah Spring Tuff vitrophyre (map unit Ttrv) up through the basal crystal-poor vitric zone of the Tiva Canyon Tuff (map unit Tcpv) and includes pre-Pah Canyon Tuff bedded tuffs (map unit Tbt2), the Pah Canyon Tuff (map unit Tpp), the Yucca Mountain Tuff (map unit Tpy), the crystal-poor vitric zone at the base of the Tiva Canyon Tuff (map unit Tcpv), and interstratified bedded tuffs (Moyer and others, 1996). Each of these units is separated by unconformities and, locally, by paleosols. The source caldera for the older part of these units (Topopah Spring Tuff through the Pah Canyon Tuff) is buried and remains uncertain. The source for the Yucca Mountain Tuff was probably the Claim Canyon Caldera (Byers and others, 1976; Sawyer and others, 1994).

The quartz-poor 12.7-Ma Tiva Canyon Tuff (Sawyer and others, 1994, p. 1305) stratigraphically overlies the nonwelded bedded units included in the PTn (see above). The source of the Tiva Canyon Tuff was the Claim Canyon Caldera north of the map area (Byers and others, 1976). Like the Topopah Spring
Tuff, the Tiva Canyon Tuff is made up of a lower crystal-poor rhyolite member (map units Tcpv, Tcplnc, Tcpln, Tcpll, Tcpum, Tcpmn, Tcpun, and Tcpul) and a crystal-rich quartz-latite member (map units Tcr1, Tcr2, Tcrn3, Tcrn4, and Tcrv). It is overlain by pumiceous, pyroclastic-flow and fallout deposits (map unit Tbt5).

Pyroclastic-flow deposits and lava flows of the rhyolite of Comb Peak (Paintbrush Group) are exposed north of Yucca Wash in the northeastern part of the map area. The vent for these units was defined by Dickerson and Drake (1995) to be at Comb Peak, just northeast of the map area. The quartz-bearing 11.6-Ma (Sawyer and others, 1994, p. 1305) Rainier Mesa Tuff, which is the oldest formation of the Timber Mountain Group, is the youngest pyroclastic unit in the map area. Its source was the Timber Mountain Caldera (Byers and others, 1976, p. 19). In the map area, the Rainier Mesa Tuff is made up of a lower nonwelded tuff overlain by a partially to moderately welded rhyolitic ash-flow tuff.

Tertiary basaltic dikes intrude the volcanic sequence along the Solitario Canyon Fault and in the vicinity of a northwest-striking fault in the northern part of the map area. Isotopic ages on a correlative brecciated basaltic dike from a trench on the saddle west of the Little Prow yields a date of $10 \pm 0.4 \mathrm{Ma}$ (Carr and Parrish, 1985). The dike that intruded along the Solitario Canyon Fault near the Little Prow is itself brecciated along the fault and implies that movement along the Solitario Canyon Fault both pre-dated and post-dated the dike (Scott, 1990).

\section{STRUCTURAL SETTING OF THE CENTRAL BLOCK AREA}

The structural grain of the central block and surrounding region is dominated by north-striking, block-bounding normal faults (fig. 1). The Solitario Canyon and the Bow Ridge Faults, which bound the central block proper, represent two such blockbounding faults.

\section{DOMINANT FAULTS IN THE CENTRAL BLOCK AREA OF YUCCA MOUNTAIN}

Establishing the relative ages and spatial distribution of faults is important to constrain the seismic 
hazards for the potential high-level nuclear waste repository at Yucca Mountain. Cross-cutting relations between faults define relative timing of fault development and, hence, the tectonic evolution of the area during and after eruption of the Tertiary Paintbrush Group. The major faults and their attendant splays can be generalized into three main groups on the basis of their orientation-north-striking block-bounding, northwest-striking, and intrablock.

Scott (1990) used the term "imbricate fault zone" for a series of closely spaced, steeply dipping faults associated with hanging wall deformation on the Bow Ridge and the Dune Wash Faults. He defined them as an "imbricate pattern of closely spaced, steep, west-dipping faults with minor down-to-the-west offsets of a few meters or less." As pointed out by Spengler and Fox (1989), the term is unclear, so we hereby abandon it. Normally, the term "imbricate faults" is used in conjunction with thrust fault zones as a series of nearly parallel and overlapping minor thrust faults, high-angle reverse faults, or slides that sole into an underlying decollement. The most recent detailed mapping shows that the fault zones referred to in figure 6 of Scott (1990) are not a series of parallel faults; more importantly, are not associated with thrust faulting; and do not sole into a true detachment structure. They are highly faulted zones on the eastern and south-central parts of the central structural block area associated with deformation in the hanging wall of the block-bounding faults (the Bow Ridge and the Dune

Wash Faults, respectively). These structural zones are made up of north- and northwest-striking faults, which have normal displacement both down to the west and down to the east with as much as 70 to $80 \mathrm{~m}$ of cumulative offset at the north end of Boundary Ridge. The current mapping shows that the zones do not meet the criteria set out by Scott (1990) and as commonly defined. As described below, these faults are believed to merge with the Bow Ridge Fault at depth in the central part of the map area and with the Dune Wash Fault south of Ghost Dance Wash in the south-central part of the map area. The term "imbricate fault zone" is used in quotes to key the reader into its usage by Scott (1990).

\section{NORTH-STRIKING BLOCK-BOUNDING FAULTS}

The regional tectonic grain of Yucca Mountain is defined by several north- to northeast-striking faults.
Two major block-bounding faults are present in the map area- the Bow Ridge to the east and the Solitario Canyon to the west. The Bow Ridge Fault forms the eastern boundary of the central block and is well exposed in trenches just west of Exile Hill and in the Exploratory Studies Facility (ESF), which is a 7.6-mdiameter tunnel beneath part of the central block area. The fault is a down-to-the-west normal fault of about $100 \mathrm{~m}$ displacement in this area. In the ESF $(40 \mathrm{~m}$ beneath the surface), the fault is a 2 -m-wide zone that dips approximately $60^{\circ}$ to the west and contains sandto gravel-sized fault gouge (Steven C. Beason, U.S. Bureau of Reclamation, oral commun., 1996).

Although not exposed in natural outcrop within the map area, the Bow Ridge Fault controls the structural grain of the eastern part of the central block. Specifically, to the west of the Bow Ridge Fault are numerous north-striking high-angle normal faults downthrown to the west and east. These faults, which are associated with Scott's (1990) "imbricate fault zone," are the result of the hanging wall deformation that is associated with the Bow Ridge Fault. The easternmost faults exposed in this zone are a series of discontinuous, east-dipping, down-to-the-east normal faults that crop out on Bleach Bone, Azreal, Live Yucca, Antler, and Boundary Ridges. These east-dipping down-to-theeast normal faults form a series of small grabens in the hanging wall of the Bow Ridge Fault that are buried beneath the alluvial cover. Flattening foliations in the tuff dip steeply to the east into the graben $\left(20\right.$ to $\left.30^{\circ}\right)$ relative to the beds to the west in the less faulted areas $\left(8^{\circ}\right.$ to $\left.15^{\circ}\right)$. Another feature of hanging wall deformation in the Bow Ridge Fault is seen in the south ESF portal area on the eastern flank of Boundary Ridge. An east-dipping reverse fault dips into the Bow Ridge Fault, recording local shortening in the Bow Ridge hanging wall. The ramifications of this are discussed below.

The Solitario Canyon Fault forms the western boundary of the central structural block. Its displacement varies considerably along its strike in that it is a "scissors" fault with down-to-the-east displacement of about $70 \mathrm{~m}$ along its northern extent in Yucca Wash. This is within the range reported by Christiansen and Lipman (1965), as well as Scott and Bonk (1984). The "hinge" of the scissorslike displacement is on the southern wall of Tea Cup Wash. North of the hinge, the Solitario Canyon Fault is a steeply dipping fault zone that is narrower than its expression to the south in Solitario Canyon. In contrast, to the south of the Little 
Prow in Solitario Canyon proper, the fault widens considerably into an anastamosing zone of faults and highly brecciated zones and is downthrown on the west with more than $500 \mathrm{~m}$ of displacement.

Within Solitario Canyon proper, the deformation associated with the Solitario Canyon Fault is a zone as much as $550 \mathrm{~m}$ wide. This region is bound on the east by a prominent west-dipping fault scarp that juxtaposes the Topopah Spring Tuff on the footwall against highly brecciated units of the Tiva Canyon Tuff in the hanging wall. The western margin of the zone lies beneath Quaternary alluvial deposits in the canyon floor (Lipman and McKay, 1965; Scott and Bonk, 1984) and juxtaposes highly brecciated panels of tectonically intermingled Tiva Canyon and Topopah Spring Tuffs in the fault zone against eastdipping hanging wall strata in the upper parts of the Tiva Canyon Tuff exposed within and to the west of the canyon floor. Locally, the region between the two bounding faults of the zone consists of a west-dipping panel of tectonized rocks, as first described by Scott and Bonk (1984). Elsewhere, the region is characterized by numerous fault splays and locally intensely brecciated rocks. Areas of abundant fault splays appear to be associated with fault bends or, locally, where displacement along the Solitario Canyon Fault zone is being transferred from one dominant fault strand to another.

Although limited because of a lack of favorable exposures, evidence indicates that the Solitario Canyon Fault was active after eruption of the Topopah Spring Tuff, but prior to deposition of the Tiva Canyon Tuff. Several fault splays of the Solitario Canyon Fault have displacement that decreases upsection from the Topopah Spring through the nonwelded units of the Pah Canyon, the Yucca Mountain, and associated tuffs and dies out in the Tiva Canyon Tuff. This could either be the result of the faults simply dying out vertically or reflect growthfault pre-Tiva offset that diminishes upward. One clear pre-Tiva Canyon Tuff growth fault, which is a splay off the Solitario Canyon Fault, is well exposed along the eastern wall midway along Solitario Canyon southwest of borehole $\mathrm{H}-\mathrm{-5}$. The nonwelded units appear to thicken across the fault, which verifies its growth nature. Offset at the top of the Topopah Spring Tuff is about $10 \mathrm{~m}$; displacement, however, dies out up-section to less than $4 \mathrm{~m}$ at the base of the Tiva Canyon Tuff, and no offset is recorded in the upper part of the Tiva Canyon Tuff (map unit Tcpul). West of borehole $\mathrm{H}-3$ are a series of small faults that also decrease in displacement up-section through the Topopah Spring and base of the Tiva Canyon Tuffs, but die out toward the top of the Tiva Canyon Tuff.

Scott (1990) suggested that incremental displacement along the Solitario Canyon Fault continued through eruption of the 11.6-Ma Rainier Mesa Tuff of the Timber Mountain Group. He cited evidence for deformation along the Solitario Canyon Fault at Plug Hill in the southwestern part of the map area, which he interpreted as a steeper eastward dip in flattening foliations within the Tiva Canyon Tuff compared with the mapped trace of the welded/ nonwelded break in the overlying Rainier Mesa Tuff. However, subsequent mapping does not confirm this structural unconformity inasmuch as there is no significant difference in eastward dip of these two units. Therefore, there is no substantiated evidence for a significant amount of offset on the Soliatio Canyon Fault as defined by increased eastward rotation of the strata in the 12.7- to 11.6-Ma time frame. This is consistent with Hudson and others (1996), who noted no difference in the orientation of the paleomagnetic pole recorded in either unit. They also concluded that there was no appreciable structural rotation of the 12.7-Ma Tiva Canyon Tuff prior to eruption of the 11.6-Ma Rainier Mesa Tuff as a result of wrench faulting associated with regional deformation within the Walker Lane region of southwestern Nevada, which includes the area of Yucca Mountain. They defined the main pulse of deformation within the Walker Lane region as post-dating eruption of the 11.6-Ma Rainier Mesa Tuff, but prior to that of the 11.45-Ma Ammonia Tanks Tuff.

\section{NORTHWEST-STRIKING FAULTS}

Three key northwest-striking faults are exposed in the northern part of the map area: the Sever Wash, the Pagany Wash, and the Drill Hole Wash. Our mapping confirms observations by Scott and others (1984) that the latest motion on the Sever Wash and the Pagany Wash Faults was dextral strike-slip. On the basis of their interpretation of aeromagnetic data, Scott and Bonk (1984) inferred the presence of a northwest-striking fault beneath Yucca Wash, which they called the Yucca Wash Fault, in the northeastern part of the central block map area. However, significant changes in volcanic facies occur across and north 
of Yucca Wash. Recent mapping north and east of Yucca Wash (mostly northeast of the map area) has delineated several block-bounding, north-striking faults (Dickerson, 1996), which can be traced in the subsurface continuously by using detailed ground magnetic data by Ponce and Langenheim (1994) south across Yucca Wash in Midway Valley (east of the map area). Furthermore, these data indicate no lateral offset of magnetic anomalies along a northweststriking feature, such as that indicated by Scott and Bonk (1984). Therefore, we have not mapped the Yucca Wash Fault that was inferred by Scott and Bonk (1984).

The main exposed trace of the Sever Wash Fault is on the southern flank of Sever Wash. It is well developed in moderately and poorly welded facies of the Yucca Mountain Tuff near the floor of the wash. The northwestern end of the Sever Wash Fault splits into several splays. Where exposed, it is a near vertical fault with silicified breccia and subhorizontal slickensides. Commonly, the long axis of mullion structures developed on the fault surfaces also are subhorizontal. A parallel fault is exposed on the canyon wall about $75 \mathrm{~m}$ south of the main fault. Between these two faults, numerous minor northweststriking faults and shears are exposed in the limited outcrop, which indicates that the strain associated with the Sever Wash Fault was dissipated over a 75-m-wide zone. One notable feature of the Sever Wash Fault, which is similar to the Pagany Wash Fault (see below), is the apparent reversal of the relative component of vertical offset along its trace length. Along the northwestern trace of the fault, the fault shows down-to-thesouthwest displacement, which changes to down to the northeast along its southeastern segment.

The Pagany Wash Fault is truncated on its northwestern end by the Solitario Canyon Fault and perhaps on the southeastern end by a north-striking down-to-the-east fault associated with the Bow Ridge Fault. Like the Sever Wash Fault, it has mesoscopic features that indicate a dextral sense of offset. Riedel shears are well developed along its trace in welded part of the Yucca Mountain Tuff at the head of Pagany Wash (Simonds and others, 1995). The Riedel shears form an acute angle (about $30^{\circ}$ ) measured clockwise from the main fault plane, which indicates dextral motion on the fault plane during the formation of the shears. In addition, subhorizontal slickensides also are developed, which indicate that the latest movement along the fault was strike-slip. There is approximately
$6 \mathrm{~m}$ of down-to-the-southwest vertical separation on the northwestern extent of the fault in Pagany Wash. However, along the southwestern trace of the fault (northwest of borehole WT\#4), there is about $10 \mathrm{~m}$ of down-to-the-northeast vertical separation. This apparent change in relative vertical displacement on the Pagany Wash and the Sever Wash Faults could be a result of dextral strike-slip motion during or after the strata were tectonically rotated into their present southeast dip direction. The rotation presumably occurred along the Bow Ridge Fault. This suggests that the Bow Ridge Fault and the main northweststriking faults were coeval (see below).

The Drill Hole Wash Fault is believed to be a system of kinematically related faults and splays. Unfortunately, the vast majority of the fault system lies buried beneath Quaternary alluvial deposits in the floor of the wash. The main trace of the fault is intersected in borehole a \#4 (Spengler and Rosebaum, 1980). In the ESF, several en echelon northweststriking faults correlated with the Drill Hole Wash Fault are seen between 1,901 and 1,942 $\mathrm{m}$ from the north portal of the ESF (Steven C. Beason, U.S. Bureau of Reclamation, oral commun., 1995). Each are downthrown to the west and have subhorizontal slickensides with a dextral sense of offset. Two such faults exposed in the ESF correlate with the fractured and sheared rocks seen by Spengler and Rosebaum (1980) in a-\#4. The faults project to the surface beneath the colluvium at the base of the northeastern flank of Drill Hole Wash near borehole NRG\#5.

The southern splay of the Drill Hole Wash Fault system is exposed on Tonsil Ridge northwest of borehole $\mathrm{H}-1$. Here, the fault strikes N. $30^{\circ} \mathrm{W}$., dips steeply 80 to $85^{\circ}$ to the southwest, has a cumulative offset of about $15 \mathrm{~m}$, and is downthrown to the southwest. Projection of this fault into the subsurface suggests that the fault intersects the ESF $2,265 \mathrm{~m}$ from the north portal entrance directly beneath the center of Drill Hole Wash. As exposed in the ESF, this fault is unique in that it is an open and uncemented breccia zone about $2 \mathrm{~m}$ wide and contains rotated blocks as much as $1 \mathrm{~m}$ long. The zone narrows to less than $1 \mathrm{~m}$ wide in the crown of the ESF. The margins of the fault are irregular owing to its open nature; on the west side of the ESF drift, the margin of the fault strikes between N. $11^{\circ} \mathrm{W}$. and N. $30^{\circ} \mathrm{W}$. and on the east side of the drift, the margin of the fault strikes $\mathrm{N} .0^{\circ}$ to $15^{\circ} \mathrm{W}$.; both sides dip to the southwest. The fault has an average strike of $\mathrm{N} .10^{\circ} \mathrm{W}$. and dips $80^{\circ}$ to the 
southwest. Apparent offset across the zone is at least $1.2 \mathrm{~m}$ down to the southwest. The variability in vertical offset along the fault trace in the $400-\mathrm{m}$ distance between Tonsil Ridge and the ESF $(15 \mathrm{~m}$ at the surface versus $1.2 \mathrm{~m}$ in the ESF) and orientation (N. $30^{\circ} \mathrm{W}$. versus N. $10^{\circ} \mathrm{W}$.) is similar to that observed on faults throughout the map area.

A previously unidentified northwest-striking fault is inferred beneath the wash near the c-hole complex (boreholes c\#1, 2, and 3) at the northern tip of Bow Ridge east of the Bow Ridge Fault. Map unit Tcpln is exposed on the northwestern tip of Bow Ridge, whereas map unit Tcpmn is exposed north of the wash along the projected strike, which requires a minimum of $20 \mathrm{~m}$ of down-to-the-northeast displacement. The relative age of this inferred fault compared with that of the Bow Ridge Fault, which is a major block-bounding fault, is unknown.

Another northwest-striking fault is inferred beneath the Quaternary deposits in the floor of Antler Wash. Like the northwest-striking fault near the c-hole complex, this fault has a northeast-side down displacement. There is an obvious stratigraphic mismatch on the opposing ridges across the wash. West of the "imbricate fault zone," the volcanic bedrock strikes to the northeast, and, as such, similar units should be exposed on both sides of the wash at the same elevations. However, the stratigraphically older units of the Tiva Canyon Tuff (map units Tcpll and Tcpln) are exposed on the southwestern side directly on strike from younger units within the Tiva Canyon Tuff (map units Tcpul and Tcpmn). The amount of relative displacement increases to the southeast. Northwest of the borehole $\mathrm{H}-4$, there is no offset documented. However, just south of borehole $\mathrm{UZ}-16$ there is about $15 \mathrm{~m}$ of northeast-side-down offset. Between the "imbricate fault zone" and the hanging wall graben associated with the Bow Ridge Fault, there is a change in strike in the bedrock units, from more northerly south of the wash to northeasterly on the north of the wash. Stratigraphic displacement may be more than $30 \mathrm{~m}$, again with the northeast-side down. The relative timing of deformation between the fault beneath Antler Wash and the north-striking faults in the "imbricate fault zone" is unknown, but the northwest-striking fault is inferred to be older than the north-striking faults.

\section{INTRABLOCK FAULTS}

Several intrablock faults formed within the central block area. These include the Sundance, the Ghost Dance, those in the hanging wall of the Bow Ridge Fault (part of the "imbricate fault zone" of Scott, 1990), and numerous small discontinuous ones.

The Sundance Fault zone is exposed south of Drill Hole Wash between Live and Dead Yucca Ridges. Spengler and others (1994) first identified the Sundance Fault as a wide zone of minor northweststriking faults that commonly show down-to-thenortheast displacement. They did not define the length of the fault. Subsequent detailed mapping by Potter and Dickerson (this report) showed that the fault zone is about $750 \mathrm{~m}$ long, extends from Dead Yucca Ridge southeastward to Live Yucca Ridge, and has a maximum cumulative down-to-the-northeast displacement of 6 to $11 \mathrm{~m}$.

The Ghost Dance Fault is the main structure within the central part of the potential repository area. In general, this fault is a north-striking normal fault zone, steeply west-dipping ( 75 to $85^{\circ}$ ) with down-tothe-west displacement. The displacement, amount of brecciation, and number of associated splays vary considerably along its trace (Spengler and others, 1993).

The Ghost Dance Fault zone can be divided into three segments on the basis of the amount of offset and brecciation. The northern segment lies north of Split Wash and is a relatively narrow damaged-rock zone ( 2 to $4 \mathrm{~m}$ wide) with as much as $6 \mathrm{~m}$ of down-to-thewest displacement. The central segment of the Ghost Dance Fault zone has greater west-side-down displacement than the northern segment and extends from Split Wash to Broken Limb Ridge. On Antler Ridge within this central segment, there are 13 to $20 \mathrm{~m}$ of cumulative displacement across several splays of the Ghost Dance that are distributed over a map width of approximately 100 to $150 \mathrm{~m}$. Individual splays are kinematically related and are characterized by a 1- to 2-m-wide damaged-rock breccia zone. On the north-facing slope of Antler Ridge, the main trace forms two overlapping strands in map view. Spengler and others (1994) suggested that the two strands were offset along a younger northwest-striking fault. However, subsequent mapping by Potter and others (1996) does not support the existence of a younger strike-slip fault. They suggested that the two Ghost Dance strands are en echelon and meet at depth and 
that the abundant breccia between the two fault tips may be indicative of a small accommodation zone between the two strands. Alternatively, the Ghost Dance Fault may have "stepped over" along a preexisting discontinuity, such as a set of closely spaced northwest-striking cooling joints. Neither hypothesis requires a separate tectonic event to explain the discontinuous nature of the Ghost Dance Fault at this location. To the south on Whale Back Ridge, the central segment of the fault zone is bounded by two splays seperated by about $55 \mathrm{~m}$ and has about $27 \mathrm{~m}$ down-to-the-west offset. The two north-striking faults, that have $1-4-\mathrm{m}$ wide damaged-rock zones, and the easternmost of which is defined as the main trace of the Ghost Dance.

The southern segment of the Ghost Dance Fault extends from Broken Limb Ridge south to where it merges with the Abandoned Wash Fault. South of borehole UZ-7a, the main fault zone bifurcates, striking to the southwest into the Abandoned Wash Fault of Scott and Bonk (1984) and to the southeast toward, but not into, the Dune Wash Fault. In the area where the Ghost Dance Fault bifurcates (on Broken Limb Ridge), it is made up of numerous fault splays that parallel the main north-striking trace of the zone and branch off the main fault laterally and vertically. Vertical "horse-tailing" is present on the south side of Whale Back Ridge and on the north-facing slope of Broken Limb Ridge.

The amount of displacement and brecciation along the southwestern projection of the Ghost Dance Fault across Highway Ridge is considerably less than that preserved along the central segment. On the south-facing slope of Broken Limb Ridge, the offset is less than $6 \mathrm{~m}$, and brecciation in the hanging wall (map unit Tcpmn) extends about $15 \mathrm{~m}$ to the west. In the Ghost Dance Wash area (near the bend eastward in the ESF), displacement on the fault is less than $3 \mathrm{~m}$. Deformation also is considerably less, defining a narrow (2-m-wide) damaged-rock zone. Offset on the fault increases to the southwest from Ghost Dance Wash, which becomes about $17 \mathrm{~m}$ of down-to-thewest displacement in Abandoned Wash on the eastern splay of the Abandoned Wash Fault (see below).

Like the Ghost Dance Fault, the north-striking Abandoned Wash Fault bifurcates along the strike, with the eastern splay connecting with the southwestern trace of the Ghost Dance Fault. The western branch extends from Abandoned Wash north across Highway Ridge and Broken Limb Ridge. The north- striking extension was not mapped as a continuous fault by Scott and Bonk (1984). They did, however, recognize breccia and small faults along the fault, as mapped here, as it crossed the ridge crests. Possibly because this branch of the fault lies within a single one of their map units, they depicted the breccia and fault offsets as small, discrete northwest-striking faults and did not recognize the continuous nature of the fault.

Establishing the relative age of motion on the Sundance and the Ghost Dance Faults is important to determine the tectonic history within the potential repository area. However, the Sundance Fault zone cannot be traced across the Ghost Dance Fault and does not offset it, contrary to the findings of Spengler and others (1994). Instead, the surface trace of the Sundance Fault terminates west of the Ghost Dance Fault. Although several minor northwest-striking faults on strike with the Sundance Fault cut parts of the crystal-poor member of the Tiva Canyon Tuff on Live Yucca Ridge, the unnamed ridge between the tributaries of Split Wash to the west of the Ghost Dance Fault, and Antler and Whaleback Ridges east of the Ghost Dance Fault, these minor faults do not appear to be thoroughgoing structures and do not define a fault zone. The main trace of the Ghost Dance Fault strikes straight across Split Wash beneath the Quaternary alluvial cover with no apparent offset along a younger fault.

In addition to the prominent northwest-striking faults in the northern part of the map area, there are several intrablock northwest-striking en echelon graben structures in the southern part of the map area on Bow Ridge and Boundary Ridge. These narrow (100-m-wide), long (as much as 750-m-long), steepwalled, "canoe-shaped" grabens have significant internal displacement, and their bounding faults locally exceed $30 \mathrm{~m}$ of displacement. On Boundary Ridge, the en echelon grabens form between the termination of splays of two major north-northeast-striking normal faults — one at the northern end of a splay of the Dune Wash Fault and the other at the southern end of a series of north-striking faults assigned to the "imbricate fault zone" of Scott (1990). 


\section{GEOGRAPHIC VARIATION OF FAULT MAGNITUDE AND RELATIVE AGE OF FAULTING}

The style and magnitude of tectonism developed after the eruption of the Tiva Canyon Tuff differs from north to south in the central structural block of Yucca Mountain. However, there is evidence for coeval development of the north- and northwest-striking fault sets. In the northern part of the map area, the physiography is dominated by northwest-trending washes, in part, underlain by the northwest-striking faults (the Drill Hole Wash, the Pagany Wash, and the Sever Wash). The Sundance Fault is herein discussed with this series of northwest-striking faults. The amount of offset and deformation associated with these faults decreases from north to south; the greatest brecciation, and more mullions, slickensides, fractures, and fault splays are associated with the Sever Wash Fault. Along its northwestern trace, the Sever Wash Fault splays in map view like several of the other dominant faults in the central block area. The Pagany Wash Fault is a narrow zone with Riedel shears developed at its intersection with the Yucca Mountain Tuff in the floor of Pagany Wash. As exposed in the ESF, the Drill Hole Wash Fault has very little breccia or associated deformation at depth. On Tonsil Ridge, breccia is associated with one of the splays, but no slickensides are observed. The Sundance Fault zone is relatively short $(750 \mathrm{~m})$ and is characterized by a series of discontinuous, small faults and shears (Potter and others, 1996). Perhaps the Sundance Fault zone can be considered as an incipient fault in this family of northwest-striking faults.

The relative timing of development on the north-striking and northwest-striking structures at Yucca Mountain is variable and often seemingly contradictory. Where exposed in the northern part of the central block, the northwest-striking faults locally intersect or are cut by the north-striking blockbounding faults. This relation is well exposed on the southeastern tip of Bleach Bone Ridge near borehole WT\#4 where the Pagany Wash Fault is cut by a northstriking down-to-the-east normal fault inferred to be associated with hanging wall deformation of the Bow Ridge Fault. In addition, the northwestern end of the Pagany Wash Fault is cut by the Solitario Canyon Fault. This could either be a cross-cutting relation or the Pagany Wash Fault could join the Solitario Canyon Fault, thus both of these faults are of the same age. Smaller north- and northeast-striking intrablock faults terminate against the northwest-striking faults. Also, the new mapping shows that on the eastern end of Azreal Ridge between boreholes NRG\#3 and

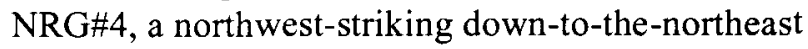
fault cuts a north-striking fault associated with Scott's (1990) "imbricate fault zone." These observations support a coeval development of the north- and northwest-trending structures.

Further evidence for coeval development of north- and northwest-trending structures is preserved in the southeastern part of the map area in the Bow and the Boundary Ridges area. North- and northweststriking faults show mutual termination relations. Several north-striking faults merge into northweststriking faults and en echelon pull-apart grabens. The northwest-striking fault buried beneath the wash between the northern tip of Bow Ridge and the hill north of the $c$-hole complex is inferred to cut the north-trending narrow graben that projects across the gap. These examples indicate that development of the north- and northwest-striking structural features was coeval and, therefore, kinematically linked.

\section{TECTONIC IMPLICATIONS}

The new mapping confirms a southward increase in deformation associated with the north- and northwest-striking faults, as well as coeval development of these post-Tiva Canyon Tuff fault sets. Assuming that there was pre-Tiva Canyon Tuff motion on the Solitario Canyon Fault, activity on the major block-bounding faults may have preceded development of the northwest-striking faults. After eruption of the Tiva Canyon Tuff, northwest- and north-striking sets of faults developed in response to progressive Miocene tectonism, which was punctuated by episodic extension.

Scott (1990) observed that, relative to the gently dipping rocks to the west of the block-bounding faults, dips within volcanic strata become steeper in the hanging walls above the block-bounding faults, such as the Solitario Canyon, the Bow Ridge, and the Dune Wash. Because the strata dip more steeply into the faults in the hanging wall, Scott concluded that the block-bounding faults were listric at depth and soled into a low-angle detachment fault estimated to be $1 \mathrm{~km}$ beneath Yucca Mountain. Recent seismic data obtained by Brocher and others (1996) show that no 
such low-angle detachment fault can be imaged at shallow depths. However, the new mapping verifies Scott's observations that the dip of the beds increases on the west side of the Solitario Canyon, the Bow Ridge, and the Dune Wash Faults, which supports their gently curving (or concave) geometry with depth. Where exposed, the block-bounding faults generally dip between 65 and $75^{\circ}$ at the surface. Preliminary interpretations of the seismic data indicate that the faults shallow slightly with depth ( 1 to $3 \mathrm{~km}$ ) to about 50 to $60^{\circ}$. Therefore, the faults form concave surfaces in that their mapped trace on the surface indicates that they dip steeply, but are thought to curve to more moderate dips $\left(50\right.$ to $\left.60^{\circ}\right)$ at depth. Assuming this general geometry, the steep "imbricate faults" in the hanging wall of the Bow Ridge Fault must join the Bow Ridge Fault at depth. In the case of the Solitario Canyon Fault, the anastamosing faults in the floor of Solitario Canyon and, possibly, the fault that cuts the middle of Jet Ridge intersect the Solitario Canyon Fault at depth. These faults, therefore, define an upward branching geometry in which the kinematically related steep- to east-dipping faults in the hanging walls bifurcate vertically toward the surface off the major block-bounding faults.

Evidence for a kinematic model comes from the orientation of slickensides on faults, which indicates the direction of the latest motion on the fault, and from the structural pattern defined by the block-bounding and intrablock faults. Unfortunately, slickensides are poorly developed along the vast majority of the faults exposed at the surface. The notable exceptions include the Solitario Canyon and the Sever Wash Faults. Simonds and others (1995) found that the slickensides plunge toward the southwest, which indicates a component of left-lateral motion associated with the dominant down-to-the-west dip-slip motion on the Solitario Canyon Fault. Mesoscopic structures on the northwest-striking faults indicate a dextral, dominantly strike-slip sense of latest offset.

A kinematic model in which sinistral strike-slip component of shear was accompanied by down-to-thewest dip-slip motion, or sinistral oblique offset, explains the structural development of the central block area (O'Neill and others, 1992). The northweststriking faults may represent large-scale intrablock shears developed between the north-striking blockbounding faults, which, in two-dimensions, represent the bounding faults in a sinistral simple shear couple regime. Oblique motion is recorded in the southern part of the map area along the Solitario Canyon Fault, along which are southwest-plunging mineral lineations developed on the fault scarp (Simonds and others, 1995). A regional left-lateral simple shear couple that acted on the block-bounding faults (the Bow Ridge and the northern part of the Dune Wash) produced the northwest-oriented grabens. These canoe-shaped grabens represent large tension gashes developed between the two block-bounding faults and their kinematically related splays. In addition, the orientation and asymmetry of the grabens are consistent with leftlateral shear.

The reverse faults on the eastern flank of Boundary Ridge and on the northern end of Bow Ridge record a regime of local compression in an overall tensile environment. The local compression could have been caused by oblique left-lateral motion on the Bow Ridge Fault, which would have caused convergence of its hanging wall against rocks in the footwall of the northwest-trending Dune Wash Fault to the west. North of the saddle between Bow and Boundary Ridges, the Bow Ridge Fault has a concave to the east map pattern. Left-lateral oblique motion would create a convergence of the hanging wall block of rocks of the Bow Ridge Fault with the Dune Wash Fault. Therefore, north of the saddle between Bow and Boundary Ridges, the main trace of the Bow Ridge Fault forms a restraining bend, which would produce a locally compressive regime, accounting for the reverse fault on the eastern flank of Boundary Ridge. To account for the reverse faults on Bow Ridge, there must have been a similar sinistral shear couple on block-bounding faults to the east of the map area (for example, on the Midway Valley or Paintbrush Canyon Faults).

\section{SYNOPSIS OF THE STRUCTURAL DEVELOPMENT}

Bedrock geologic mapping forms the foundation for development of any valid tectonic model (Day and others, 1996; Dickerson, 1996; Potter and others, 1996; Sweetkind and others, 1996). As such, conclusions based on the detailed geologic map developed here must be woven into tectonic models for Yucca Mountain. The bedrock geologic mapping is consistent with the following generalizations:

1. The major north-south block-bounding faults developed in response to regional east-west extension 
after eruption of the 12.8-Ma Topopah Spring Tuff. Extension continued throughout the eruption of the 12.7-Ma Tiva Canyon Tuff. Support for this is noted by growth-faulting along a splay of the Solitario Canyon Fault accompanied by apparent stratigraphic thickening of the Pah Canyon Tuff along one such growth fault.

2. Eruption of the Tiva Canyon Tuff was temporally associated with coeval north- and northweststriking faulting. Evidence for this is exposed along Solitario Canyon wherein apparent stratigraphic thickening occurs in the pre-Tiva Canyon Tuff bedded tuffs along a growth fault.

3. Extension on the steeply dipping, albeit gently curving, block-bounding faults caused rotation of the beds into the hanging wall of the blockbounding faults. Regional dextral shear associated with the northwest-striking Walker Lane tectonic belt (Hudson and others, 1994, 1996) may have caused clockwise steep-axis rigid-body rotation of the structural blocks defined by the north-south block-bounding faults (Rosenbaum and Snyder, 1985; Scott, 1990; Rosenbaum and others, 1991; O'Neill and others, 1992). Appreciable deformation associated with the dextral shearing and steep-axis clockwise rotation occurred within the broad Walker Lane tectonic region between eruptions of the 11.6-Ma Rainier Mesa Tuff and the 11.45-Ma Ammonia Tanks Tuff, the later of which is not preserved in the map area (Hudson and others, 1996). Such clockwise rotation of north/south oriented structural blocks yielded a component of sinistral shear along the block-bounding normal faults. If true, then the sinistral shearing, which was coupled with east/west extension, generated the northwest-trending faults and en echelon grabens, which could be viewed as large-scale tension gashes.

4. At 10-Ma, basaltic dikes intruded along the Solitario Canyon Fault and northwest-striking faults in the northern part of the map area.

\section{Regionally, Quatemary to Recent extension} continued on some of the major block-bounding faults. However, the only evidence for Recent motion is observed in trenches across the Soli- tario Canyon and the Bow Ridge Faults in the central block area (Simonds and others, 1995).

\section{REFERENCES CITED}

Brocher, T.M., Hart, P.E., Hunter, C.W., and Langenheim, V.E., 1996, Hybrid-source seismic reflection profiling across Yucca Mountain, Nevada-Regional lines 2 and 3: U.S. Geological Survey Open-File Report 96-28, $97 \mathrm{p} ., 6 \mathrm{pl}$.

Buesch, D.C., Nelson, J.E., Dickerson, R.P., Drake, R., Spengler, R.W., Geslin, J.K., Moyer, T.C., San Juan, C.A., and Selger, T., 1995, Distribution of lithostratigraphic units within the central block of Yucca Mountain, Nevada-A three-dimensional computer-based model, version YMP.R2.0: U.S. Geological Survey Open-File Report 95-124, 47 p.

Buesch, D.C., Spengler, R.W., Moyer, T.C., and Geslin, J.K., 1996, Proposed stratigraphic nomenclature and macroscopic identification of lithostratigraphic units of the Paintbrush Group exposed at Yucca Mountain, Nevada: U.S. Geological Survey Open-File Report 94-469, 45 p.

Byers, F.M., Jr., Carr, W.J., Orkild, P.P., Quinlivan, W.D., and Sargent K.A., 1976, Volcanic suites and related cauldrons of Timber Mountain-Oasis Valley caldera complex, southern Nevada: U.S. Geological Survey Professional Paper 919,69 p

Carr, W.J., 1986, Volcano-tectonic setting of Yucca Mountain and Crater Flat, southwestern Nevada, in Carr, D., and Yount, J.C., eds., Geologic and hydrologic investigations of a potential nuclear waste disposal site at Yucca Mountain, southern Nevada: U.S. Geological Survey Bulletin 1790, p. 35-49

Carr, W.J., and Parrish, L.D., 1985, Geology of borehole USW VH-2, and structure of Crater Flat, southwestern Nevada: U.S. Geological Survey Open-File Report 85-475, $41 \mathrm{p}$.

Christiansen, R.L., and Lipman, P.W., 1965, Geologic map of the Topopah Spring northwest quadrangle, Nye County, Nevada: U.S. Geological Survey Geologic Quadrangle Map GQ-444, scale 1:24,000, 1 sheet.

Day, W.C., Potter, C.J., Sweetkind, D.S., and Dickerson, R.P., 1996, Detailed bedrock geologic map of the central block area, Yucca Mountain--Implications for structural development of the potential high-level radioactive waste repository area in Nye County, Nevada [abs.]: Geological Society of America Abstracts with Program, v. 28, no. 7, p. A-248.

Dickerson, R.P., 1996, Geologic and geophysical evidence for normal faulting in Yucca Wash, Yucca Mountain, Nevada [abs.]: Geological Society of America Abstracts with Program, v. 28, no. 7, p. A191-A192. 
Dickerson, R.P., and Drake, R.M., III, 1995, Source of the rhyolite at Comb Peak, southwest Nevada volcanic field [abs.]: Geological Society of America Abstracts with Programs, v. 27, no. 4, p. 8.

Geslin, J.K., and Moyer, T.C., 1995, Surnmary of lithologic logging of new and existing boreholes at Yucca Mountain, Nevada, March 1994 to June 1994: U.S. Geological Survey Open-File Report 94 451, 16 p.

Geslin, J.K., Moyer T.C., and Buesch, D.C., 1995, Summary of lithologic logging of new and existing boreholes at Yucca Mountain, Nevada, August 1993 to February 1994: U.S. Geological Survey Open-File Report 94-342, $39 \mathrm{p}$

Hudson, M.R., Minor, S.A., and Fridrich, C.J., 1996, The distribution, timing, and character of steep-axis rotations in a broad zone of dextral shear in southwestern Nevada [abs.]: Geological Society of America, Abstracts with Programs, Annual Meeting, v. 28, no. 7 p. A-451

Hudson, M.R., Sawyer, D.A., and Warren, R.G., 1994, Paleomagnetism and rotation constraints for the middle Miocene southwestern Nevada volcanic field: Tectonics, v. 13, no. 2, p. 258-277.

Lipman, P.W., and McKay, E.J., 1965, Geologic map of the Topopah Spring southwest quadrangle, Nye County, Nevada: U.S. Geological Survey Geologic Quadrangle Map GQ-439, scale 1:24,000, 1 sheet.

Montazer, P., and Wilson, W.E., 1984, Conceptual hydrologic model of flow in the unsaturated zone, Yucca Mountain, Nevada: U.S. Geological Survey WaterResources Investigations Report 84-4345, $55 \mathrm{p}$.

Moyer, T.C., Geslin, J.K., and Buesch, D.C., 1995, Summary of lithologic logging of new and existing boreholes at Yucca Mountain, Nevada, July 1994 to November 1994: U.S. Geological Survey Open-File Report 95-102, $27 \mathrm{p}$.

Moyer, T.C., Geslin, J.K., and Flint, L.E., 1996, Stratigraphic relations and hydrologic properties of the Paintbrush Tuff nonwelded (PTn) hydrologic units, Yucca Mountain, Nevada: U.S. Geological Survey Open-File Report 95-397, $151 \mathrm{p}$.

O'Neill, J.M., Whitney, J.W., and Hudson, M.R., 1992, Photogeologic and kinematic analysis of lineaments at Yucca Mountain, Nevada-Implications for strike-slip faulting and oroclinal bending. U.S. Geological Survey Open-File Report 91-623, 23 p.

Ponce, D.A., and Langenheim, V.E., 1994, Preliminary gravity and magnetic models across Midway Valley and Yucca Wash, Yucca Mountain, Nevada: U.S. Geological Survey Open-File Report 94-572, 25 p.

Potter, C.J., Day, W.C., and Sweetkind, D.S., 1996, Structural evolution of the potential high-level nuclear waste repository site at Yucca Mountain, Nevada [abs.]: Geological Society of America Abstracts with Program, v. 28, no. 7, p. A-191.

Rosenbaum, J.G., Hudson, M.R., and Scott, R.B., 1991, Paleomagnetic constraints on the geometry and timing of deformation at Yucca Mountain, Nevada: Journal of Geophysical Research, v. 96, no. B2, p. 1963-1979.

Rosenbaum, J.G., and Snyder, D.B., 1985, Preliminary interpretation of paleomagnetic and magnetic property data from boreholes $\mathrm{G}-1, \mathrm{G}-2, \mathrm{GU}-3, \mathrm{G}-3$, and $\mathrm{VH}-1$ and surface localities in the vicinity of Yucca Mountain, Nye County, Nevada: U.S. Geological Survey Open-File Report 85-49, 73 p.

Sawyer, D.A., Fleck, R.J., Lanphere, M.A., Warren, R.G., Broxton, D.E., and Hudson, M.R., 1994, Episodic caldera volcanism in the Miocene southwestern Nevada volcanic field--Revised stratigraphic framework, $40 \mathrm{Ar} / 39 \mathrm{Ar}$ geochronology, and implications for magmatism and extension: Geological Society of America Bulletin, v. 106, p. 1304-1318.

Scott, R.B., 1990, Tectonic setting of Yucca Mountain, southwest Nevada: Geological Society of America Memoir 176, p. 251-282.

Scott, R.B., Bath, G.D., Flanigan, V.J., Hoover, D.B., Rosenbaum, J.G., and Spengler, R.W., 1984, Geological and geophysical evidence of structures in northwest-striking washes, Yucca Mountain, southern Nevada, and their possible significance to a nuclear waste repository in the unsaturated zone: U.S. Geological Survey Open-File Report 84-567, $23 \mathrm{p}$.

Scott, R.B., and Bonk, Jerry, 1984, Preliminary geologic map of Yucca Mountain, Nye County, Nevada, with geologic sections: U.S. Geological Survey Open-File Report 84-494, scale 1:12,000, 2 sheets.

Simonds, F.W., Whitney, J.W., Fox, K.F., Ramelli, A.R., Yount, J.C., Carr, M.D., Menges, C.M., Dickerson, R.P., and Scott, R.B., 1995, Map showing fault activity in the Yucca Mountain area, Nye County, Nevada: U.S. Geological Survey Miscellaneous Investigations Series I-2520, scale 1:24,000, 1 sheet.

Spengler, R.W., Braun, C.A., Linden, R.M., Martin, L.G., Ross-Brown, D.M., and Blackburn, R.L., 1993, Structural character of the Ghost Dance Fault, Yucca Mountain, Nevada, in High Level Radioactive Waste Management Proceedings of the Fourth International Conference: Las Vegas, American Nuclear Society, v. 1., p. $653-659$.

Spengler, R.W., Braun, C.A., Martin, L.G., and Weisenberg, C.W., 1994, The Sundance Fault-A newly recognized shear zone at Yucca Mountain, Nevada: U.S. Geological Survey Open-File Report 94-49, 11 p.

Spengler, R.W., and Fox, K.F., Jr., 1989, Stratigraphic and structural framework of Yucca Mountain, Nevada: Radioactive Waste Management and the Nuclear Fuel Cycle, v. 13, p. 21-36. 
Spengler, R.W., and Rosenbaum, J.G., 1980, Preliminary interpretations of geologic results obtained from boreholes UE25a-4, -5,-6, and -7, Yucca Mountain,

Nevada Test Site: U.S. Geological Survey Open-File Report 80-929, 33 p.

Sweetkind, D.S., Beason, S.C, Potter, C.J., Lung, R., Day, W.C., and Barr, D., 1996, Correlation between surface and subsurface features at Yucca Mountain, Nye

County, Nevada [abs.]: Geological Society of America

Abstracts with Program, v. 28, no. 7, p. A-521. 
This is a placeholder page for records that cannot be scanned or microfilmed

1. Record Date 04/17/97

2. Author Name(s)

DAY WC; POTTER CH; SWEETKIND D; DICKERSON P

4. Title

MAP I-2601: BEDROCK GEOLOGIC MAP OF THE CENTRAL BLOCK AREA, YUCCA MOUNTAIN, NYE COUNTY, NEVADA(C)

5. Document Number(s)

N/A

7. Document Type

PUBLICATION

8. Medium

PAPER
10. Accession Number

3. Author Organization

USGS
ATT TO: MOL.19980611.0339

9. Access Control Code

PUB

11. Traceability Designator

N/A

12. Comments

THIS OVERSIZED, COLOR MAP CAN BE LOCATED THROUGH THE RECORDS PROCESSING CENTER 


\section{Error}

An error occurred while processing this page. See the system log for more details. 

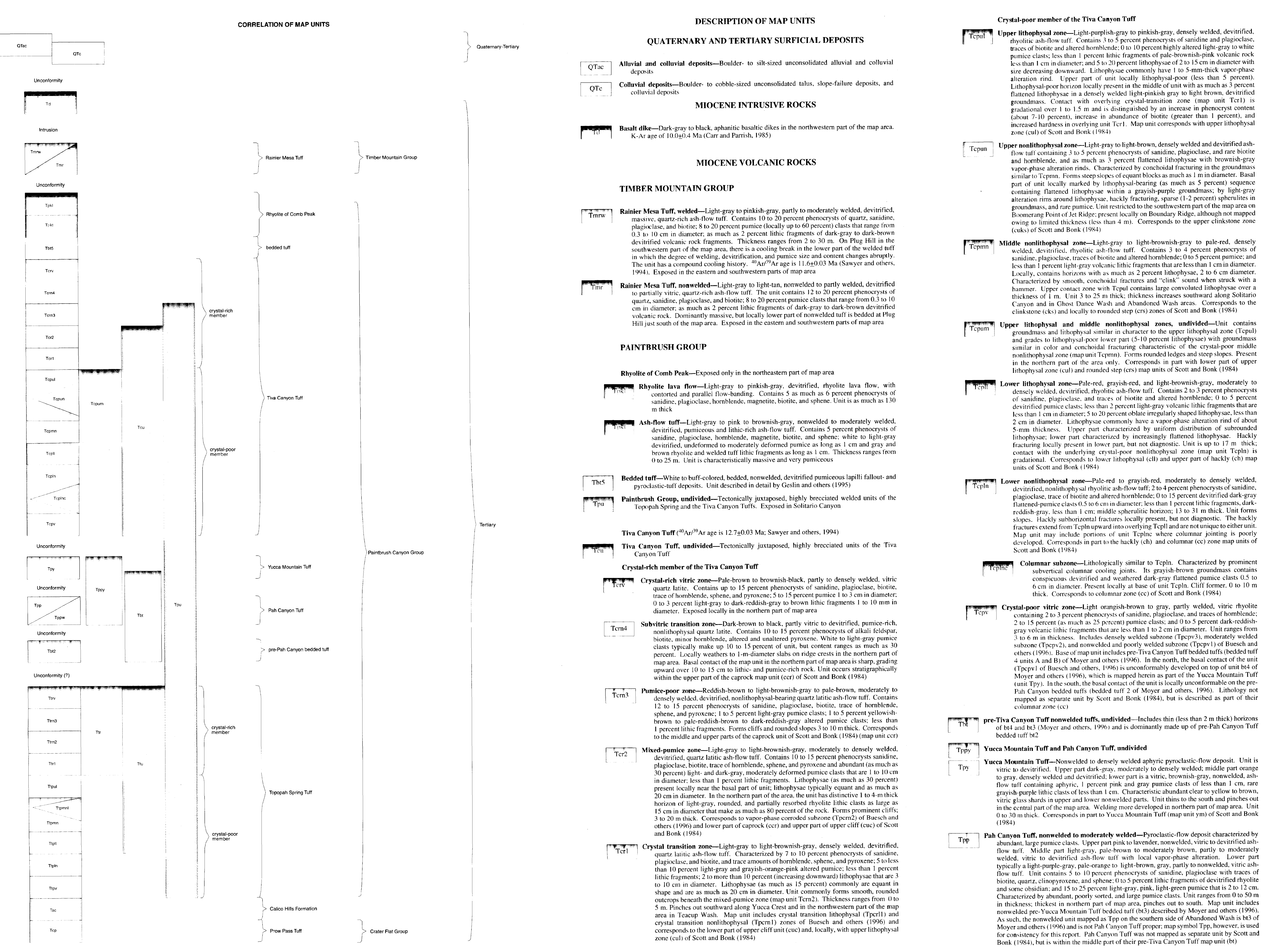

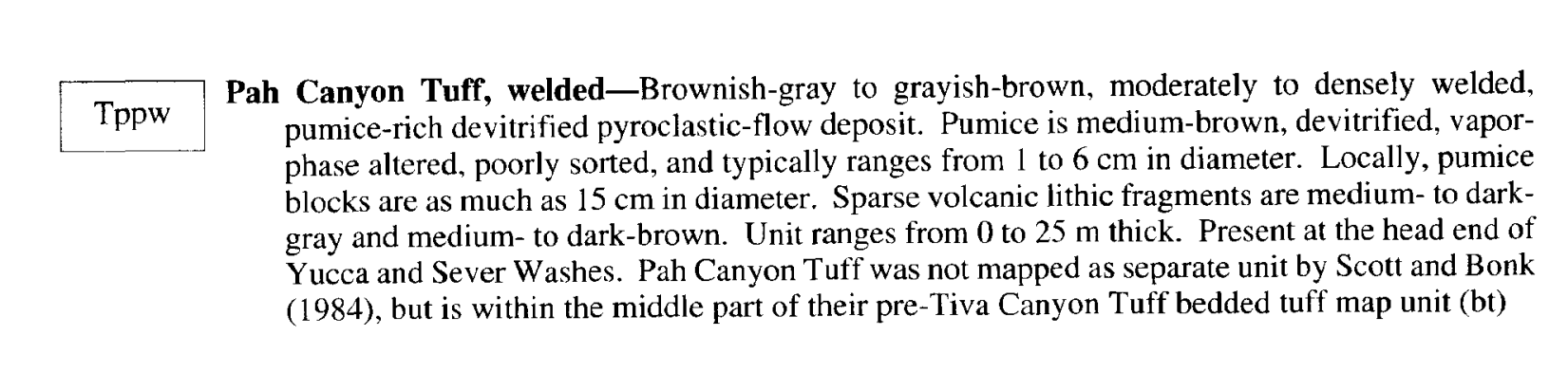

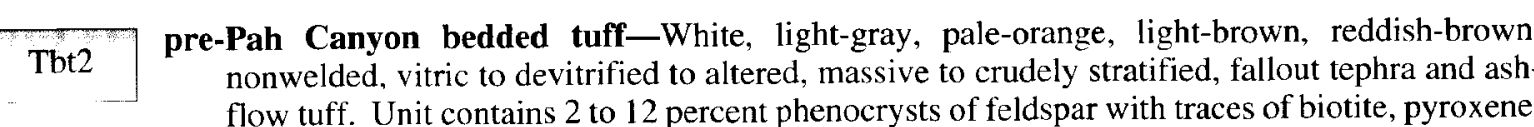

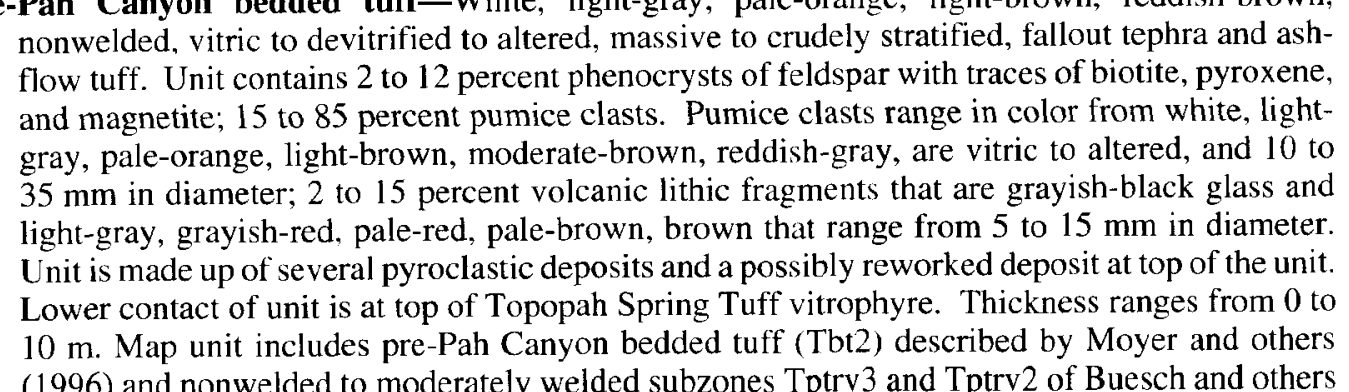

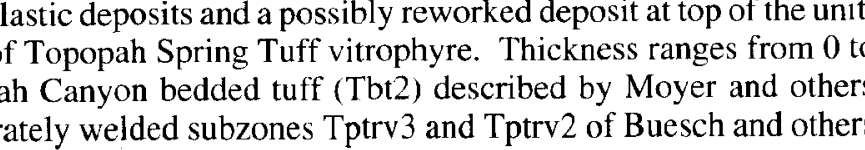

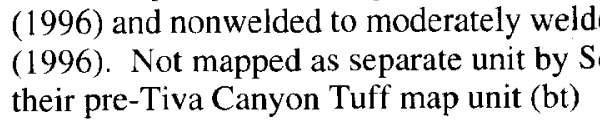

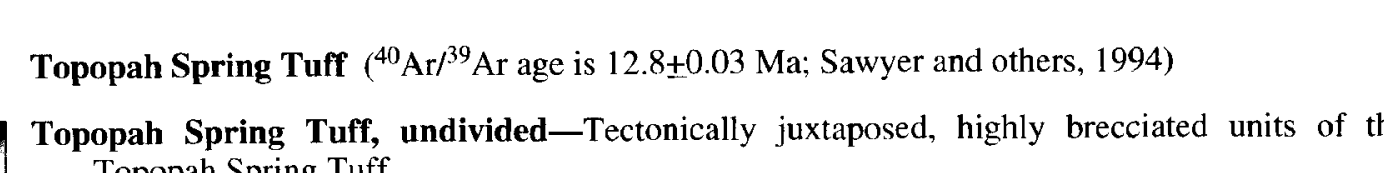

Thit $\mathrm{Cry}$

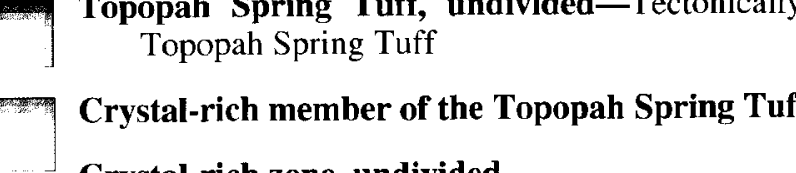

Crystal-inc hone, undivider

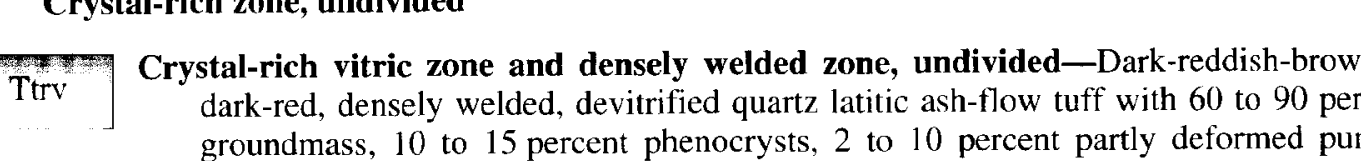

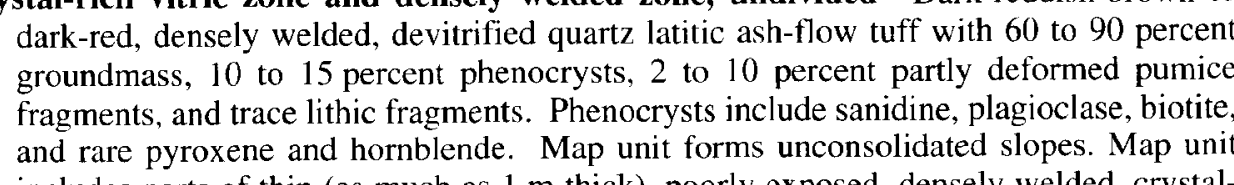

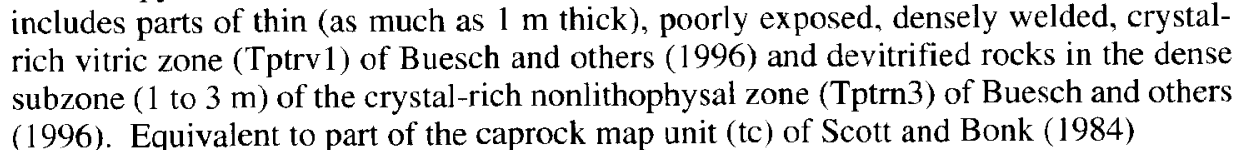

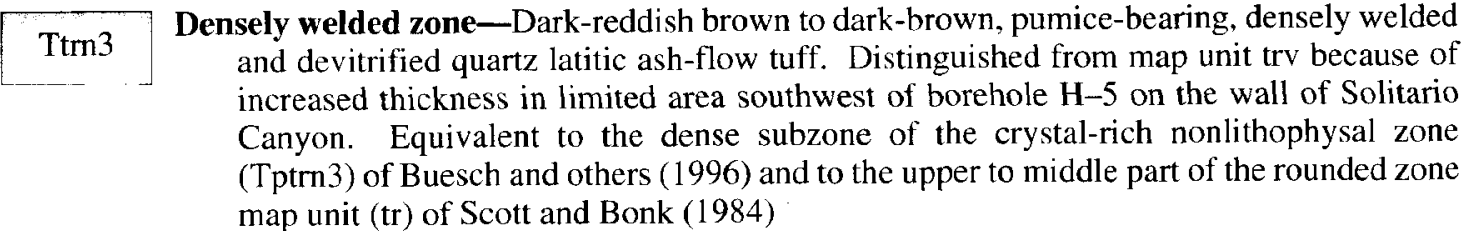

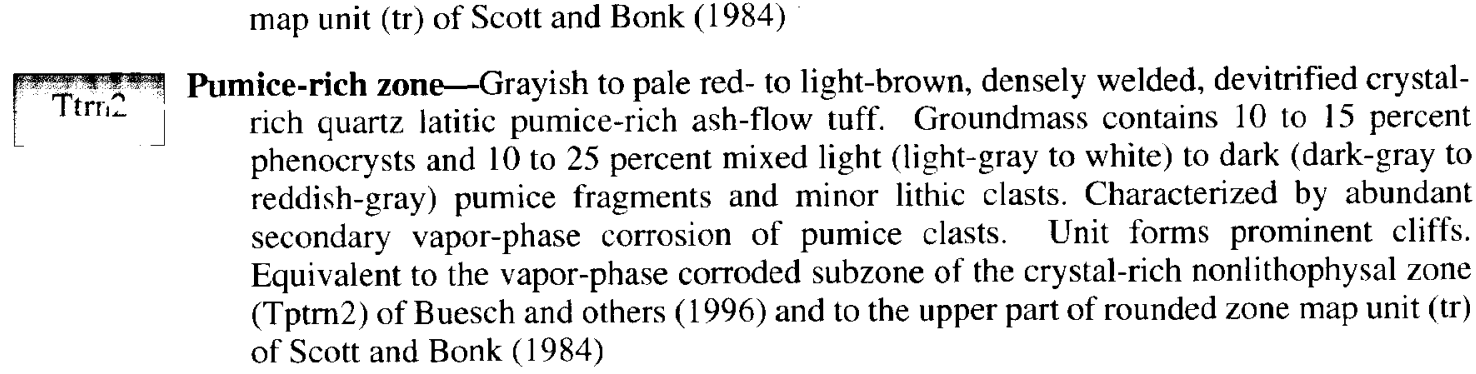

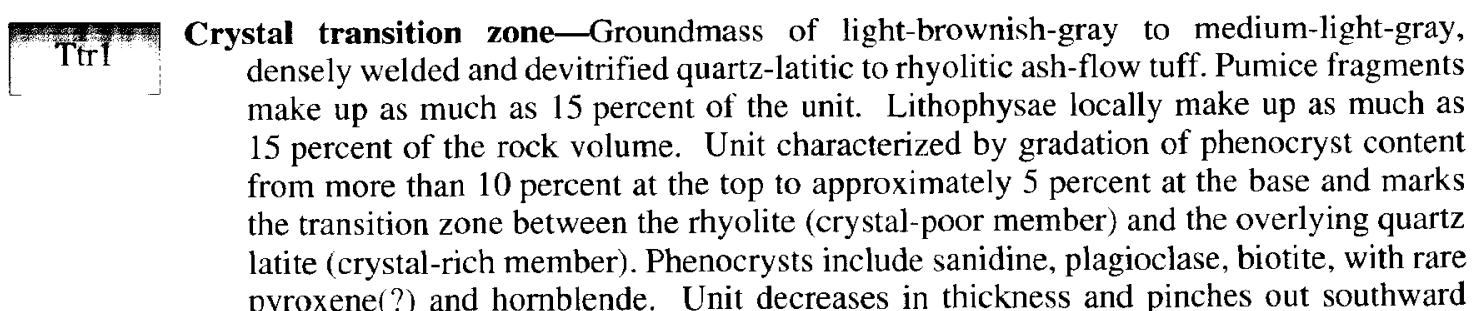

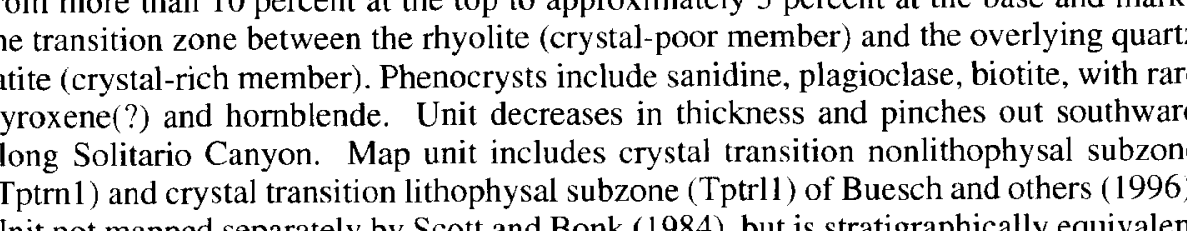

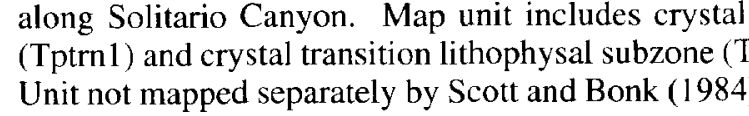

Crystal-porr member of fthe Topopant Spring uurf

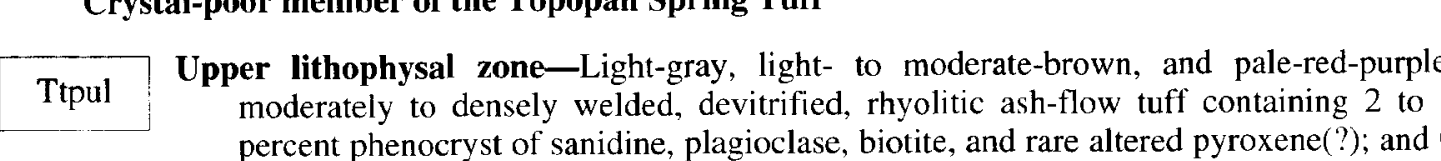

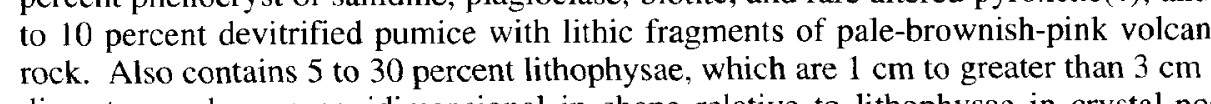

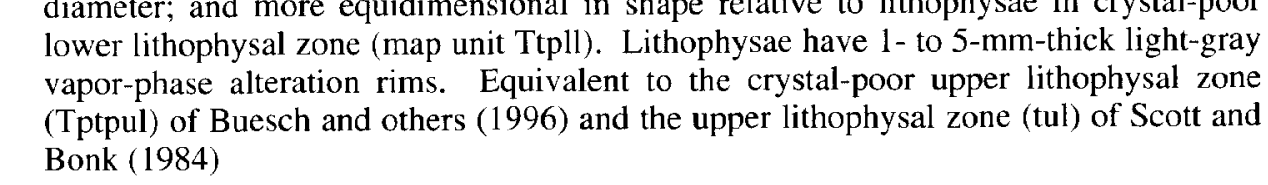

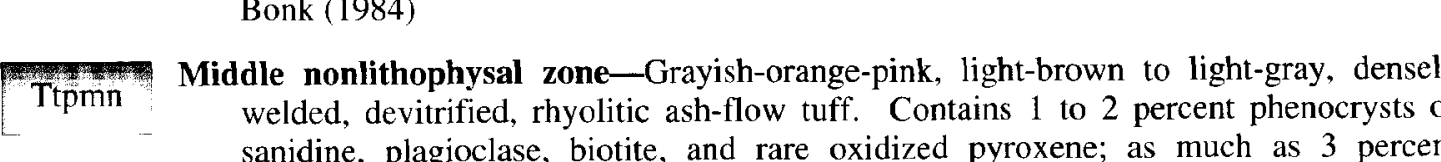

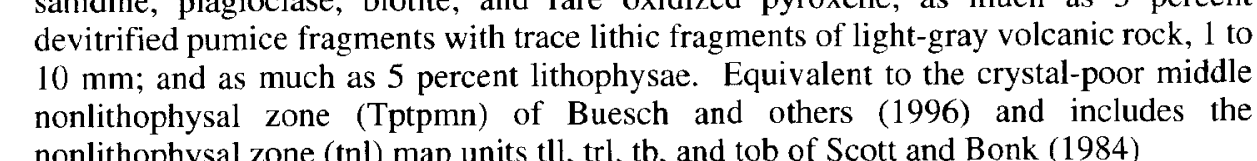

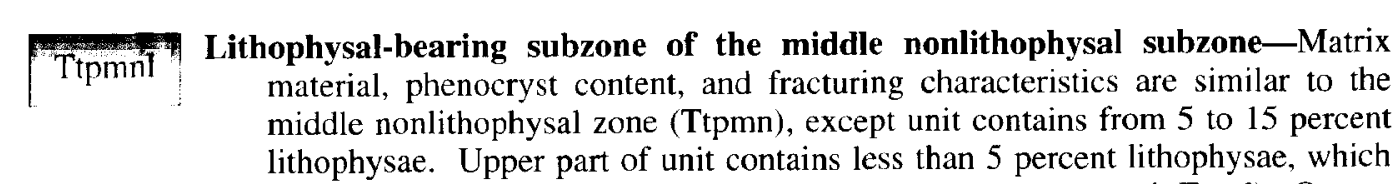

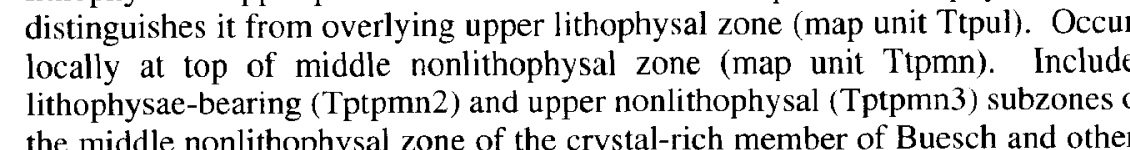

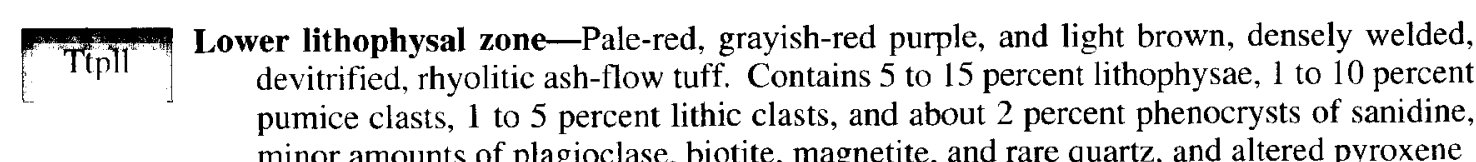

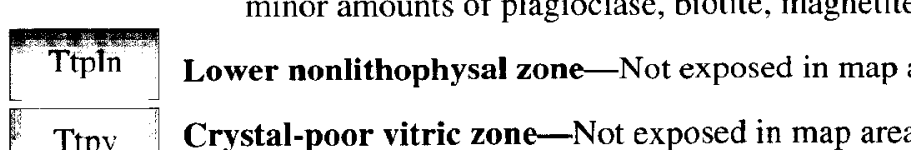

Tien Calic fill Firm CRATER FLATS GROUP
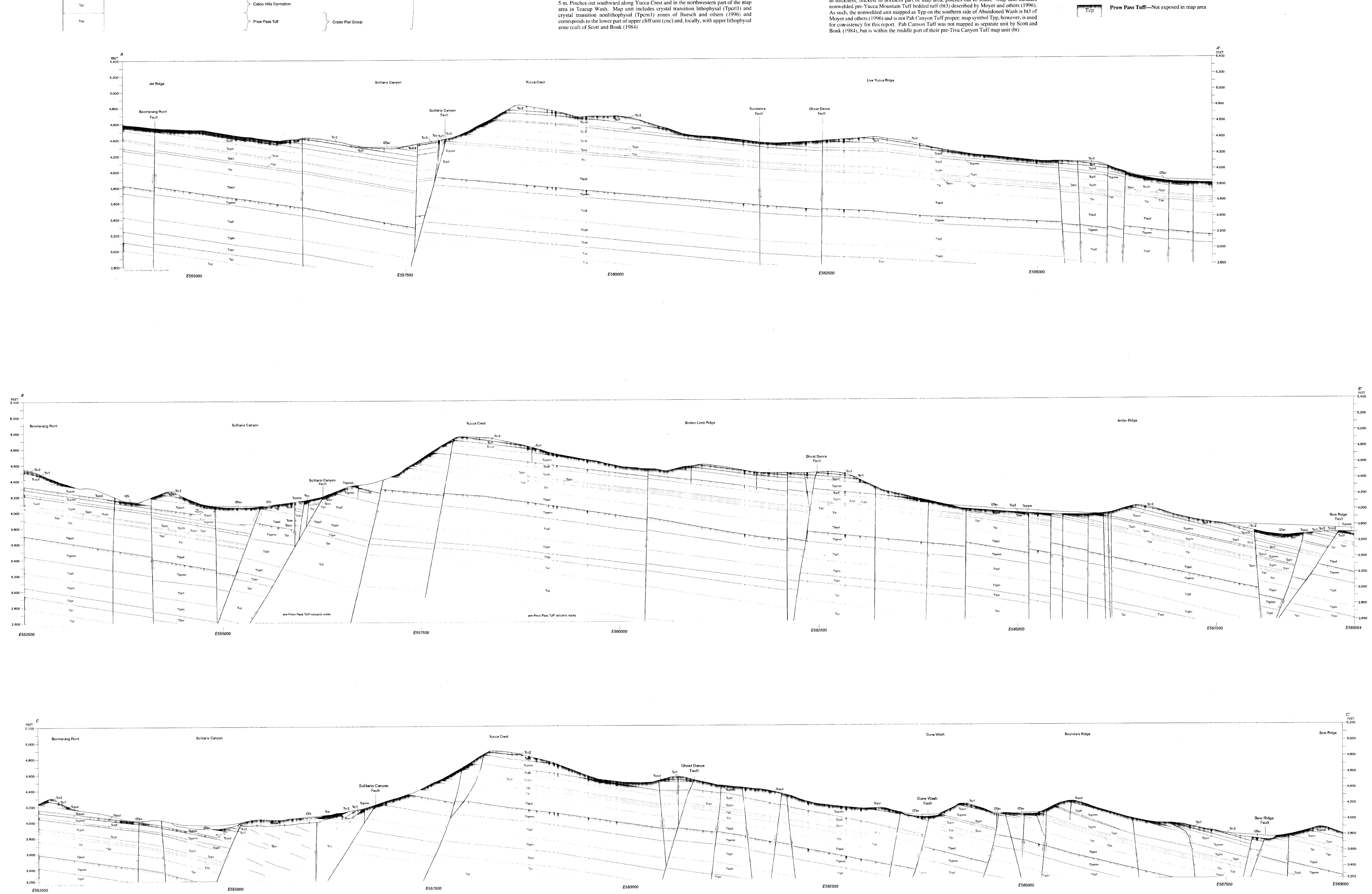

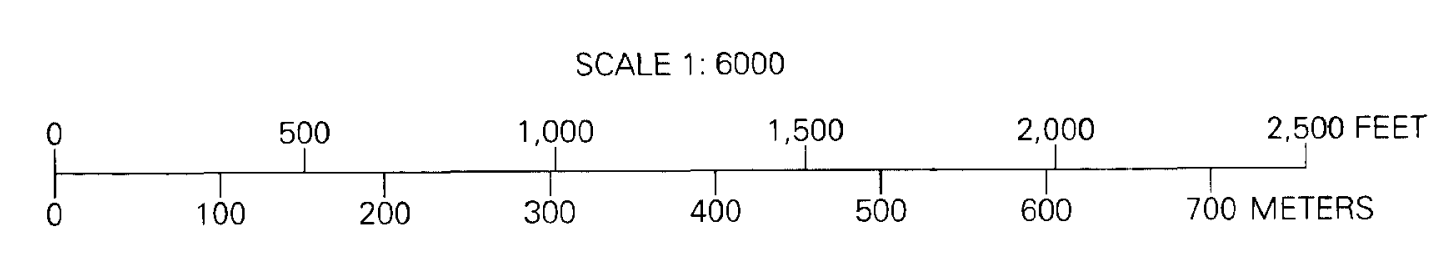

BEDROCK GEOLOGIC MAP OF THE CENTRAL BLOCK AREA, YUCCA MOUNTAIN, NYE COUNTY, NEVADA

W.C. Day, C.J. Potter, D.S. Sweetkind, P.R. Dickerson, and C.A. San Juan 